Article

\title{
Synthesis and Preliminary Evaluation of a 2-Oxoquinoline Carboxylic Acid Derivative for PET Imaging the Cannabinoid Type 2 Receptor
}

Linjing Mu ${ }^{1, *}$, Roger Slavik ${ }^{2}$, Adrienne Müller ${ }^{2}$, Kasim Popaj ${ }^{1}$, Stjepko Čermak $^{2}$, Markus Weber ${ }^{3}$, Roger Schibli ${ }^{1,2}$, Stefanie D. Krämer ${ }^{2}$ and Simon M. Ametamey ${ }^{2}$

1 Center for Radiopharmaceutical Sciences of ETH-PSI-USZ, Department of Nuclear Medicine, University Hospital Zürich, CH-8091 Zürich, Switzerland

2 Center for Radiopharmaceutical Sciences of ETH-PSI-USZ, Institute of Pharmaceutical Sciences, Department of Chemistry and Applied Biosciences, ETH Zurich, CH-8093 Zürich, Switzerland

3 Neuromuscular Diseases Unit/ALS Clinic, Kantonsspital St. Gallen, CH-9007 St. Gallen, Switzerland

* Author to whom correspondence should be addressed; E-Mail: linjing.mu@usz.ch.

Received: 20 January 2014; in revised form: 21 February 2014 / Accepted: 27 February 2014 / Published: 6 March 2014

\begin{abstract}
Cannabinoid receptor subtype 2 (CB2) has been shown to be up-regulated in activated microglia and therefore plays an important role in neuroinflammatory and neurodegenerative diseases such as multiple sclerosis, amyotrophic lateral sclerosis and Alzheimer's disease. The CB2 receptor is therefore considered as a very promising target for therapeutic approaches as well as for imaging. A promising 2-oxoquinoline derivative designated KP23 was synthesized and radiolabeled and its potential as a ligand for PET imaging the CB2 receptor was evaluated. $\left[{ }^{11} \mathrm{C}\right] \mathrm{KP} 23$ was obtained in $10 \%-25 \%$ radiochemical yield (decay corrected) and 99\% radiochemical purity. It showed high stability in phosphate buffer, rat and mouse plasma. In vitro autoradiography of rat and mouse spleen slices, as spleen expresses a high physiological expression of CB2 receptors, demonstrated that $\left[{ }^{11} \mathrm{C}\right] \mathrm{KP} 23$ exhibits specific binding towards CB2. High spleen uptake of $\left[{ }^{11} \mathrm{C}\right] \mathrm{KP} 23$ was observed in dynamic in vivo PET studies with Wistar rats. In conclusion, $\left[{ }^{11} \mathrm{C}\right] \mathrm{KP} 23$ showed promising in vitro and in vivo characteristics. Further evaluation with diseased animal model which has higher CB2 expression levels in the brain is warranted.
\end{abstract}


Keywords: cannabinoid receptor type 2 ligand; CB2 receptor; neurodegeneration; radiolabeling; autoradiography; small-animal PET

\section{Introduction}

The use of cannabis as a therapeutic agent dates back about 5,000 years with descriptions of its numerous effects including alterations in mood, cognitive functions, memory and perception of the user [1]. The plant cannabis sativa, commonly known as marijuana contains over 60 compounds. The major psychoactive constituent is delta-9-tetrahydrocannabinol $\left(\Delta^{9}\right.$-THC). Cannabinoids exert their effects through an endogenous cannabinoid system in the central and peripheral nervous system. Currently two subtypes of cannabinoid receptors have been isolated and cloned: CB1 and CB2. There is also some evidence that other cannabinoid receptors GPR18 and GPR55 may exist [2,3]. Not much is known about GPR18 and GPR55 subtypes and current research efforts in the field of cannabinoid receptors are directed towards exploring their pharmacology and physiological roles. The $\mathrm{CB} 1$ receptor is the most studied receptor of the endocannabinoid system and is densely expressed in the CNS by many classes of neurons [4,5]. The CB2 receptor on the other hand is found predominantly in cells of the immune system, spleen, lymph nodes but has very low or undetectable expression levels in the CNS under basal conditions [6,7]. Under pathological conditions, however, the CB2 receptor can be up-regulated on activated microglia (macrophages of the brain). It is well known that cannabinoid receptors are involved in a broad range of processes including appetite, anxiety, memory, cognition, immune regulation and inflammation [8], however, the function of CB2 in neuroinflammation, microglia activation and intrusion of immune cells is not yet fully understood. Visualization and quantification of CB2 receptor expression by non-invasive PET imaging provides a high potential for understanding the role of CB2 in the development and progression of neuroinflammatory and neurodegenerative diseases.

In the past decade, substantial progress has been made in the synthesis and evaluation of radiotracers for PET imaging of the CB1 receptor [9-11]. [ $\left.{ }^{18} \mathrm{~F}\right] \mathrm{MK}-9470$ has been used in the clinical setting to support CB1 receptor drug development for measuring receptor occupancy, to investigate $\mathrm{CB} 1$ receptor variability with gender and normal ageing and in studying pathophysiological conditions [12-14]. Although the pharmacological and therapeutic potential of selective CB2 ligands has been studied and reviewed extensively in the literature $[15,16]$, the field of non-invasive CB2 imaging remains largely unexplored. Only a limited number of CB2 radioligands have been synthesized and tested as PET tracers [17-21], among them the 2-oxoquinoline-3-carboxamide derivative, $\left[{ }^{11} \mathrm{C}\right] \mathrm{NE} 40$, which has been evaluated in healthy volunteers. $\left[{ }^{11} \mathrm{C}\right] \mathrm{NE} 40$ exhibited the expected uptake in lymphoid tissue and appropriate brain kinetics [22]. Herein, we report the radiolabeling, in vitro and in vivo evaluation of a 2-oxoquinoline containing structure, $\left[{ }^{11} \mathrm{C}\right] \mathrm{KP} 23$, as a potential PET radiotracer for imaging cannabinoid type 2 receptors. 


\section{Experimental Section}

\subsection{Materials and Methods}

Animal experiments were in accordance with the Swiss Animal Welfare legislation and were approved by the Veterinary Office of the Canton Zurich. Six week old female NMRI mice and male Wistar rats were purchased from Charles River (Sulzfeld, Germany) and kept under standard conditions.

All chemicals, unless otherwise stated, were purchased from Sigma-Aldrich (Zug, Switzerland) or Merck (Buchs, Switzerland) and used without further purification. Solvents for extractions, column chromatography and thin layer chromatography (TLC) were purchased as commercial grade. Organic reactions were monitored by TLC analysis using Sigma-Aldrich silica gel 60 plates $(2-25 \mu \mathrm{m})$. Mobile phase for TLC was a mixture of pentane and ethyl acetate at suitable ratios. Developed TLCs were visualized under UV light at $254 \mathrm{~nm}$. Nuclear magnetic resonance (NMR) spectra $\left({ }^{1} \mathrm{H}\right.$ and $\left.{ }^{13} \mathrm{C}-\mathrm{NMR}\right)$ were recorded in Fourier transform mode at the field strength specified on Bruker Avance FT-NMR spectrometers. The measured chemical shifts are reported in $\delta$ (ppm) and the residual signal of the solvent was used as the internal standard. Multiplicities in the ${ }^{1} \mathrm{H}-\mathrm{NMR}$ spectra are described as: $\mathrm{s}=$ singlet, $\mathrm{d}=$ doublet, $\mathrm{t}=$ triplet, $\mathrm{m}=$ multiplet, $\mathrm{b}=$ broad; coupling constants are reported in Hz. High resolution mass spectrometry (HRMS) was performed with a Bruker FTMS 4.7 T BioAPEXII spectrometer.

High-performance liquid chromatography (HPLC) analyses were performed using a reversed phase column (ACE column, C18, $3 \mu \mathrm{m}$ ). The mobile phase consisted of $0.1 \%$ TFA in water and acetonitrile. The acetonitrile gradient from $30 \%$ to $95 \%$ over $10 \mathrm{~min}$ at $1 \mathrm{~mL} / \mathrm{min}$ flow rate was applied. Analytical radio-HPLC was performed on an Agilent 1100 series system equipped with a Raytest Gabi Star radiodetector (Agilent Technologies, Morges, Switzerland). Semi-preparative HPLC purifications

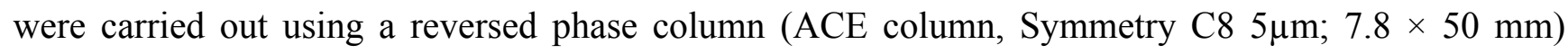
under the following conditions: $0.1 \% \mathrm{H}_{3} \mathrm{PO}_{4}$ in $\mathrm{H}_{2} \mathrm{O}$ (solvent $\mathrm{A}$ ), $\mathrm{MeCN}$ (solvent $\mathrm{B}$ ); $0.0-1.0 \mathrm{~min}, 30 \%$ B; 1.1-12.0 min, 30\%-90\% B; 12.1-20 min, 90\% B; 20.1-40 min, 30\% B; flow rate: $4 \mathrm{~mL} / \mathrm{min}$. A Merck-Hitachi L2130 system equipped with a radiation detector VRM 202 (Veenstra Instrument, Joure, the Netherlands) was used for semi-preparative HPLC. Specific activity was calculated by comparing ultraviolet peak intensity of the final formulated products with calibration curves of corresponding non-radioactive standards of known concentrations. For the in vitro and ex vivo stability studies, an Ultra-performance liquid chromatography (UPLC ${ }^{\text {TM}}$ ) system from Waters with a Waters Acquity UPLC BEH C18 column $(2.1 \times 50 \mathrm{~mm}, 1.7 \mu \mathrm{m})$ and an attached Berthold co-incidence detector (FlowStar LB513, Berthold Technologies, Bad Wildbad,) was used. The mobile phase consisted of a gradient of acetonitrile in water with $0.1 \%$ TFA from $10 \%$ to $95 \%$ over 2 min, flow rate $0.6 \mathrm{~mL} / \mathrm{min}$.

\subsection{Chemistry}

2.2.1. Synthesis of Compound 7 as Precursor for ${ }^{18}$ F-Radiolabeling

To a solution of 8-butoxy- $N$-(2-hydroxy-2-phenylethyl)-7-methoxy-2-oxo-1,2-dihydroquinoline-3carboxamide $(6,615 \mathrm{mg}, 1.5 \mathrm{mmol})$ in dichloromethane (DCM, $5 \mathrm{~mL}$ ) was added triethylamine 
(300 mg, $3.0 \mathrm{mmol}$ ). The mixture was cooled to $0{ }^{\circ} \mathrm{C}$ in an ice-bath and a solution of methanesulfonyl chloride (205 mg, $1.8 \mathrm{mmol}$ ) in DCM (3 mL) was added dropwise. The mixture was stirred over night at RT. The reaction mixture was diluted with EtOAc $(200 \mathrm{~mL})$ and washed with $0.2 \mathrm{M}$ aq. $\mathrm{HCl}$ $(3 \times 20 \mathrm{~mL})$ and brine $(2 \times 10 \mathrm{~mL})$. The organic layer was dried over $\mathrm{Na}_{2} \mathrm{SO}_{4}$ and solvents were removed under reduced pressure. The crude was purified over $100 \mathrm{~g}$ silica gel using EtOAc/Hexan 1:1 afforded 8-butoxy- $N$-(2-chloro-2-phenylethyl)-7-methoxy-2-oxo-1,2-dihydroquinoline-3-carboxamide (7, $263 \mathrm{mg}, 0.614 \mathrm{mmol}, 41 \%$ yield), but not the expected mesylated product. ${ }^{1} \mathrm{H}-\mathrm{NMR}$ (400 MHz, $\left.\mathrm{CDCl}_{3}\right): \delta 10.00(\mathrm{t}, J=5.7 \mathrm{~Hz}, 1 \mathrm{H}), 9.30(\mathrm{~s}, 1 \mathrm{H}), 8.85(\mathrm{~s}, 1 \mathrm{H}), 7.48-7.44(\mathrm{~m}, 3 \mathrm{H}), 7.40-7.31(\mathrm{~m}, 3 \mathrm{H}), 6.94$ $(\mathrm{d}, J=4.5 \mathrm{~Hz}, 1 \mathrm{H}), 5.15\left(\mathrm{dd}, J_{1}=5.4 \mathrm{~Hz}, J_{2}=8.5 \mathrm{~Hz}, 1 \mathrm{H}\right), 4.18-4.07(\mathrm{~m}, 3 \mathrm{H}), 3.97(\mathrm{~s}, 3 \mathrm{H}), 3.94-3.87$ (m, 1H), 1.83-1.76 (m, 2H), 1.55-1.46 (m, 2H), 0.99 (t, J= 7.4 Hz, 3H). HRMS: calculated for [M+H] ${ }^{+}$ $\mathrm{C}_{23} \mathrm{H}_{26} \mathrm{ClN}_{2} \mathrm{O}_{4}$ is 429.1581 ; found 429.1576 ; Purity by HPLC: $98 \%$.

\subsubsection{Synthesis of Compound KP26 as Precursor for ${ }^{11} \mathrm{C}$-Radiolabeling}

To a solution of 8-butoxy- $N$-(2-fluoro-2-phenylethyl)-7-methoxy-2-oxo-1,2-dihydroquinoline-3carboxamide (KP23, $660 \mathrm{mg}, 1.6 \mathrm{mmol})$ in DMF $(15 \mathrm{~mL})$ was added lithium chloride (1.36 g, $32 \mathrm{mmol}$ ). The mixture was heated to reflux for 4 hours. After cooling to RT, the mixture was diluted with EtOAc $(400 \mathrm{~mL})$ and washed with aq. $\mathrm{HCl}(0.2 \mathrm{M}, 3 \times 30 \mathrm{~mL})$ and brine $(2 \times 30 \mathrm{~mL})$ and dried over $\mathrm{Na}_{2} \mathrm{SO}_{4}$. Solvents were removed under reduced pressure and column chromatography of the crude over $200 \mathrm{~g}$ silica gel using EtOAc/hexane/EtOH 1:1:0.1 gave pure 8-butoxy- $N$-(2-fluoro-2-phenylethyl)7-hydroxy-2-oxo-1,2-dihydroquinoline-3-carboxamide (KP26, $458 \mathrm{mg}, 1.150 \mathrm{mmol}, 71.8 \%$ yield). ${ }^{1} \mathrm{H}-\mathrm{NMR}\left(400 \mathrm{MHz}, \mathrm{CDCl}_{3}\right): \delta 9.91(\mathrm{~s}, 1 \mathrm{H}), 9.23(\mathrm{~s}, 1 \mathrm{H}), 8.84(\mathrm{~s}, 1 \mathrm{H}), 8.50($ br. s, $1 \mathrm{H}), 7.34(\mathrm{~d}$, $J=8.7 \mathrm{~Hz}, 1 \mathrm{H}), 7.28-7.22(\mathrm{~m}, 1 \mathrm{H}), 7.05-7.00(\mathrm{~m}, 2 \mathrm{H}), 6.98-6.95(\mathrm{~m}, 1 \mathrm{H}), 6.90\left(\mathrm{dt}, J_{1}=2.1 \mathrm{~Hz}\right.$, $\left.J_{2}=8.4 \mathrm{~Hz}, 1 \mathrm{H}\right), 4.13(\mathrm{t}, J=6.9 \mathrm{~Hz}, 2 \mathrm{H}), 3.77-3.71(\mathrm{~m}, 2 \mathrm{H}), 2.95(\mathrm{t}, J=7.2 \mathrm{~Hz}, 2 \mathrm{H}), 1.83-1.76(\mathrm{~m}$, 2H), $1.52-1.43(\mathrm{~m}, 2 \mathrm{H}), 0.96(\mathrm{t}, J=7.4 \mathrm{~Hz}, 3 \mathrm{H}) .{ }^{13} \mathrm{C}-\mathrm{NMR}\left(100 \mathrm{MHz}, \mathrm{CDCl}_{3}\right): \delta 164.3,162.1,145.4$, 133.9, 131.0, 130.0, 129.9, 125.9, 124.5, 124.4, 115.8, 115.5, 114.3, 113.58, 113.5, 113.3, 73.8, 41.0, 35.5, 32.2, 19.1, 13.8. HRMS: calculated for $[\mathrm{M}+\mathrm{H}]^{+} \mathrm{C}_{22} \mathrm{H}_{24} \mathrm{~N}_{2} \mathrm{O}_{4}$ is 399.1715; found 399.1711; Purity by HPLC: $98 \%$.

\subsection{Radiochemistry}

\subsubsection{Radiosynthesis of $\left[{ }^{18} \mathrm{~F}\right] \mathrm{KP} 23$}

No-carrier-added (n.c.a) $\left[{ }^{18} \mathrm{~F}\right]$ fluoride was produced via the ${ }^{18} \mathrm{O}(\mathrm{p}, \mathrm{n}){ }^{18} \mathrm{~F}$ nuclear reaction using an IBA Cyclone 18/9 cyclotron (IBA, Ottignies-Louvain-la-Neuve, Belgium). For this, $>98 \%$ isotopically enriched ${ }^{18} \mathrm{O}$-water (Nukem GmbH, city, Germany) was irradiated by $18 \mathrm{MeV}$ proton beams. Produced $\left[{ }^{18} \mathrm{~F}\right]$ fluoride $/\left[{ }^{18} \mathrm{O}\right]$ water solution was transferred using a helium stream from the target to a shielded hot cell equipped with a manipulator where radiosynthesis was performed. The activity was trapped on a QMA cartridge (preconditioned with $0.5 \mathrm{M}$ aq. $\mathrm{K}_{2} \mathrm{CO}_{3}(1 \times 5 \mathrm{~mL})$ and then $\mathrm{H}_{2} \mathrm{O}(1 \times 5 \mathrm{~mL})$ and dried in air. The trapped $\left[{ }^{18} \mathrm{~F}\right]$ fluoride was eluted from the cartridge and eluted with a solution of Kryptofix $\left(\mathrm{K}_{2.2 .2}, 5 \mathrm{mg}\right)$ and $\mathrm{K}_{2} \mathrm{CO}_{3}(1 \mathrm{mg})$ in acetonitrile $(1.4 \mathrm{~mL})$ and water $(0.6 \mathrm{~mL})$ or tetrabutylammonium hydroxide $(0.6 \mathrm{~mL}, 0.18 \mathrm{mM})$ into a $10 \mathrm{~mL}$ sealed reaction vessel. The $\left[{ }^{18} \mathrm{~F}\right]$ fluoride (ca. $10-15 \mathrm{GBq}$ ) was dried by azeotropic distillation of acetonitrile at $110{ }^{\circ} \mathrm{C}$ under 
vacuum with a stream of nitrogen. The azeotropic drying process was repeated 3 times with $1 \mathrm{~mL}$ of acetonitrile. To the dried $\mathrm{K}_{2.2 .2} / \mathrm{K}\left[{ }^{18} \mathrm{~F}\right] \mathrm{F}$ complex was added the chlorinated compound 7 (ca. $2 \mathrm{mg}$ ) in different anhydrous solvents such as DMF, DMSO or acetonotrile $(0.3 \mathrm{~mL})$, and the reaction mixture was heated and analyzed by HPLC.

\subsubsection{Radiosynthesis of $\left[{ }^{11} \mathrm{C}\right] \mathrm{KP} 23$}

Carbon-11 was produced via the ${ }^{14} \mathrm{~N}(\mathrm{p}, \alpha){ }^{11} \mathrm{C}$ nuclear reaction at a Cyclone $18 / 9$ cyclotron $(18 \mathrm{MeV}$, IBA) in the form of $\left[{ }^{11} \mathrm{C}\right] \mathrm{CO}_{2}$. $\left[{ }^{11} \mathrm{C}\right]$ Methyl iodide $\left(\left[{ }^{11} \mathrm{C}\right] \mathrm{MeI}\right)$ was generated in a 2-step reaction sequence involving the catalytic reduction of $\left[{ }^{11} \mathrm{C}_{\mathrm{CO}_{2}}\right.$ to $\left[{ }^{11} \mathrm{C}\right]$ methane and subsequent gas phase iodination. $\left[{ }^{11} \mathrm{C}\right] \mathrm{KP} 23$ was prepared by reaction of the desmethyl precursor compound $(0.5-1 \mathrm{mg})$ with $\left[{ }^{11} \mathrm{C}\right] \mathrm{MeI}$ (ca. 40-50 GBq) in DMF solution in the presence of $\mathrm{Cs}_{2} \mathrm{CO}_{3}(5 \mathrm{mg})$ at $120{ }^{\circ} \mathrm{C}$ for $3 \mathrm{~min}$. The crude product was diluted with water $(1.3 \mathrm{~mL})$ and injected onto a semi-preparative HPLC. The radiolabeled product was collected, diluted with water $(10 \mathrm{~mL})$, passed through a preconditioned C18 cartridge (Waters, Boston, MA, USA, preconditioned with $5 \mathrm{~mL}$ EtOH and $10 \mathrm{~mL}$ water), washed with water $(5 \mathrm{~mL})$, and eluted with EtOH $(0.5 \mathrm{~mL})$. After adding $9.5 \mathrm{~mL}$ of water, the $5 \%$ ethanol solution containing $\left[{ }^{11} \mathrm{C}\right] \mathrm{KP} 23$ was then passed through a sterile filter $(0.2 \mu \mathrm{m})$ and used for all in vitro/in vivo studies.

\subsection{In Vitro Characterization}

\subsubsection{Competition Binding Assay}

Frozen membrane preparations from CHO-K1 cells transfected with human CB1 (hCB1) and CB2 (hCB2), respectively (PerkinElmer, Waltham, MA, USA), were thawed on ice and diluted to a final protein concentration of $1 \mu \mathrm{g} / \mathrm{mL}$ in assay buffer $(50 \mathrm{mM}$ TRIS/HCl, $1 \mathrm{mM}$ EDTA (Applichem, Darmstadt, Germany), $3 \mathrm{mM} \mathrm{MgCl}$, $\mathrm{pH} 7.4$, containing $0.05 \%$ bovine serum albumin, BSA). Membrane dilutions $\left(0.5 \mu \mathrm{g}\right.$ protein in $550 \mu \mathrm{L}$ final volume) were incubated at $30{ }^{\circ} \mathrm{C}$ with $\mathrm{KP} 23$ at concentrations between $10^{-5}$ and $10^{-11} \mathrm{M}$ and $1.4 \mathrm{nM}\left[{ }^{3} \mathrm{H}\right] \mathrm{CP}-55,940$ (PerkinElmer, Waltham, MA, USA), a hCB1 and hCB2 agonist with $\mathrm{K}_{\mathrm{i}}$ values of 0.58 and $0.68 \mathrm{nM}$, respectively. Nonspecific binding of $\left[{ }^{3} \mathrm{H}\right] \mathrm{CP}-55,940$ was determined after addition of $5 \mu \mathrm{M}$ hCB1/hCB2 agonist WIN-55212-2 ( $\mathrm{K}_{\mathrm{i}} 1.89$ and $0.28 \mathrm{nM}$, respectively) [23]. All samples were prepared in triplicates. After $90 \mathrm{~min}, 3 \mathrm{~mL}$ ice cold assay buffer was added and samples were immediately filtered through Whatman GF/C filters (pre-soaked in $0.05 \%$ polyethylenimine) and washed twice with $3 \mathrm{~mL}$ ice cold assay buffer. Bound $\left[{ }^{3} \mathrm{H}\right] \mathrm{CP}-55,940$ was quantified in a Beckman LS 6500 Liquid Scintillation Counter (Beckman ${ }^{\mathrm{TM}}$, Brea, $\mathrm{CA}$, USA) and $\mathrm{IC}_{50}$ values were determined by non-linear regression analysis [24]. $\mathrm{K}_{\mathrm{i}}$ values were determined with the equation from Cheng-Prusoff and are means from three independent experiments $\left(\mathrm{K}_{\mathrm{D}}\right.$ values of 0.14 and $0.11 \mathrm{nM}$ from PerkinElmer were used for $\left[{ }^{3} \mathrm{H}\right] \mathrm{CP}-55,940$ binding to hCB1 and hCB2 receptors, respectively).

\subsubsection{In Vitro Stability Studies}

To test the plasma stability of the radioligand, $10 \mu \mathrm{L}(4 \mathrm{MBq})$ of $\left[{ }^{11} \mathrm{C}\right] \mathrm{KP} 23$ solution were added to phosphate buffer $\left(300 \mu \mathrm{L}, 4 \mathrm{mM} \mathrm{NaH}{ }_{2} \mathrm{PO}_{4} / \mathrm{Na}_{2} \mathrm{HPO}_{4}, 155 \mathrm{mM} \mathrm{NaCl}, \mathrm{pH} 7.4\right)$, mouse and rat plasma 
$(300 \mu \mathrm{L})$, respectively. The mixture was vortexed and four aliquots of $70 \mu \mathrm{L}$ were incubated at $37{ }^{\circ} \mathrm{C}$. Ice cold acetonitrile $(100 \mu \mathrm{L})$ was added to stop the enzymatic reactions at different time points $(0,10$, 20 and $40 \mathrm{~min})$. After centrifugation $(10,000 \mathrm{~g}, 3 \mathrm{~min})$, the supernatant was passed through a filter ( $0.45 \mu \mathrm{m}$, Minisart SRP 4, Sartorius Stedim Biotech, Goettingen, Germany) and analyzed by UPLC.

\subsubsection{In Vitro Autoradiography}

In vitro autoradiography with $\left[{ }^{11} \mathrm{C}\right] \mathrm{KP} 23$ was performed on $20 \mu \mathrm{m}$ tissue slices (rat/mouse spleen) adsorbed to SuperFrost Plus slides. Slices were thawed $(10 \mathrm{~min})$ on ice before pre-incubation with incubation buffer (50 mM TRIS/HCl, pH 7.4, containing 5\% BSA) at $4{ }^{\circ} \mathrm{C}$ for $10 \mathrm{~min}$. Excess solution was carefully removed and the tissue slices were dried in a ventilated hood for $10 \mathrm{~min}$. Then slides were incubated with 0.6 or $0.2 \mathrm{nM}\left[{ }^{11} \mathrm{C}\right] \mathrm{KP} 23$ alone or together with specific $\mathrm{CB} 2$ agonist (GW405833, $1 \mu \mathrm{M})$ in incubation buffer. After incubation for $15 \mathrm{~min}$ at RT in a humid chamber, slides were washed twice with ice cold washing buffer (50 mM TRIS/HCl, $\mathrm{pH} 7.4,1 \% \mathrm{BSA}, 5 \% \mathrm{EtOH})$ for 2 min each and dipped twice in water. Dried slides were exposed to a phosphor imager plate for $30 \mathrm{~min}$ and the plate was scanned in a BAS5000 reader (Fujifilm, Dielsdorf, Switzerland).

\subsection{In Vivo Characterization}

\subsubsection{In Vivo PET Imaging}

PET scanning was performed with the GE VISTA eXplore PET/CT tomograph (Sedecal, Madrid, Spain). The scanner is characterized by high sensitivity (absolute central point source sensitivity of $4 \%$ for the 250-700 eV energy windows) and an axial field of view of $4.8 \mathrm{~cm}$ [25]. Male Wistar rats $(278 \pm 2 \mathrm{~g}, \mathrm{n}=2)$ were immobilized by isoflurane inhalation and the tracer was injected into a tail vein on the tomographic bed [26]. Tracer accumulation in the spleen or brain were recorded by dynamic one-bed position PET scans over 60 min starting with the injection of 13 respectively $40 \mathrm{MBq}(0.05$ to $0.15 \mathrm{nmol})$ of $\left[{ }^{11} \mathrm{C}\right] \mathrm{KP} 23$. PET data was reconstructed by 3-dimensional FORE/2-dimensional OSEM in user-defined time frames with a voxel size of $0.3875 \times 0.3875 \times 0.775 \mathrm{~mm}$. Singles and random corrections but no attenuation correction were applied. Image files were evaluated with the software PMOD v3.4 (PMOD Technologies Inc., Zurich, Switzerland). Time activity curves (TACs) of brain regions were generated with the implemented rat brain region of interest (ROI) template and TACs of the abdominal region with the respective ROIs generated by the PMOD segmentation tool. Spleen, liver and background TACs were confirmed by analysis of manually drawn regions of interest. Standardized uptake values (SUV) were calculated as tissue activities $\left(\mathrm{Bq} / \mathrm{cm}^{3}\right)$, normalized to the injected dose per body weight $(\mathrm{Bq} / \mathrm{g})$.

\subsubsection{Metabolite Studies}

$\left[{ }^{11} \mathrm{C}\right] \mathrm{KP} 23$ was administered intravenously to a restrained Wistar rat (413 g) by tail vein injection (ca. $160 \mathrm{MBq}$ ). The animal was sacrificed by decapitation $30 \mathrm{~min}$ p.i. and blood and urine were collected. Whole blood was collected in heparin-coated tubes (BD Vacutainers, Plymouth, UK) and centrifuged at $5,000 \mathrm{~g}$ for $5 \mathrm{~min}, 4{ }^{\circ} \mathrm{C}$. The proteins of the supernatant plasma and urine were precipitated by addition of an equal volume of acetonitrile and centrifuged at $5,000 \mathrm{~g}$ for another 
5 min. The supernatants were filtered and analyzed by UPLC. For the determination of in vivo radiometabolites at $15 \mathrm{~min}$ p.i. blood samples were withdrawn from the tail vein opposite to the injection site.

\section{Results and Discussion}

\subsection{Chemistry and Radiochemistry}

The non-radioactive standard reference compound KP23 was synthesized based on the modified procedure described by Turkman [27]. Compound 2 was obtained in 30\% yield by the aromatic nitration of 3-hydroxy-4-methoxybenzaldehyde (1) with nitric acid. Then $O$-alkylation with 1-bromobutane afforded compound 3 in 89\% yield. Reduction of compound 3 using iron powder followed by reaction in situ with dimethyl malonate yielded compound 4. The acid compound $\mathbf{5}$ was produced quantitatively by saponification reaction of the methyl ester compound $\mathbf{4}$ under basic conditions. Amide bond formation using the acid compound 5 with either 2-amino-1-phenylethanol or 2-fluoro-2phenylethanamine free base led to compound 6 and KP23, respectively. Compound $\mathbf{6}$ was reacted with mesylchloride to afford chloro derivative 7, which was used as supposed to be a precursor for fluorine-18 labeling. Demethylation of compound KP23 was performed with LiCl to afford the precursor compound KP26 for carbon-11 labeling. The newly synthesized compounds were characterized by mass spectrometry and NMR and their chemical purities were assessed by HPLC.

The structure of compound KP23 (Scheme 1) is amenable to radiolabeling with either fluorine-18 or carbon-11 (Scheme 2), therefore, the corresponding chloro and phenolic precursor compounds 7 and KP26 were prepared and tested for radiolabeling. For the fluorine-18 radiolabeling of KP23, it was originally planned to synthesize a precursor with a sulfonate leaving group. Initial attempts to tosylate compound $\mathbf{6}$ to afford a precursor with a tosyl leaving group were unsuccessful. Mesylation, however, exclusively afforded chloro analog 7 in $41 \%$ yields. This result has also been observed for other similar compounds in the literature $[28,29]$. It is suggested that this conversion occurs via spontaneous displacement of the sulfonate group by nitrogen (anchimeric assistance) with formation of reactive aziridinium ion intermediate. Consequent collapse of the aziridinium ion pair to the more stable chloride then occurs, upon exchange of the mesylate counterion with chloride [30]. ${ }^{18} \mathrm{~F}$-radiolabeling was unsuccessful even using different solvents e.g., MeCN, DMF or DMSO and combined with different $\left[{ }^{18} \mathrm{~F}\right]$-reagents such as $\mathrm{K}_{2.2 .2} / \mathrm{K}\left[{ }^{18} \mathrm{~F}\right] \mathrm{F}$ or $\left[{ }^{18} \mathrm{~F}\right] \mathrm{TBAF}$. Neither increasing the reaction temperature, duration of the radiolabeling reaction nor precursor concentrations had any positive influence on the outcome of radiolabeling yield. This can be explained by the fact that chloride is a poor leaving group.

KP23 was successfully labeled with carbon-11 in a one-step reaction by reacting the phenolic precursor with $\left[{ }^{11} \mathrm{C}\right]$ methyl iodide (Scheme 2). $\left[{ }^{11} \mathrm{C}\right] \mathrm{KP} 23$ (ca. 1-3 GBq) was obtained in 99\% radiochemical purity after semi-preparative HPLC purification. The total radiolabeling time was around $40 \mathrm{~min}$ after delivery of $\left[{ }^{11} \mathrm{C}\right] \mathrm{CO}_{2}$ from the cyclotron to the hot-cell. Specific activity was high and ranged from 80 to $240 \mathrm{GBq} / \mu \mathrm{mol}$ at the end of synthesis. The radiochemical yield was $10 \%-25 \%$ (decay corrected). 
Scheme 1. Synthesis of the standard reference KP23 and precursors 7 and KP26 for radiolabeling.<smiles>CCOC(=O)c1ccc(OC)c(O)c1</smiles><smiles>COc1ccc(C=O)c([N+](=O)[O-])c1O</smiles>

2

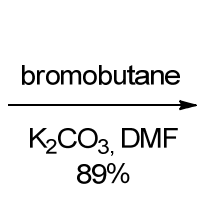<smiles>CCCCOc1c(OC)ccc(C=O)c1[N+](=O)[O-]</smiles>

3

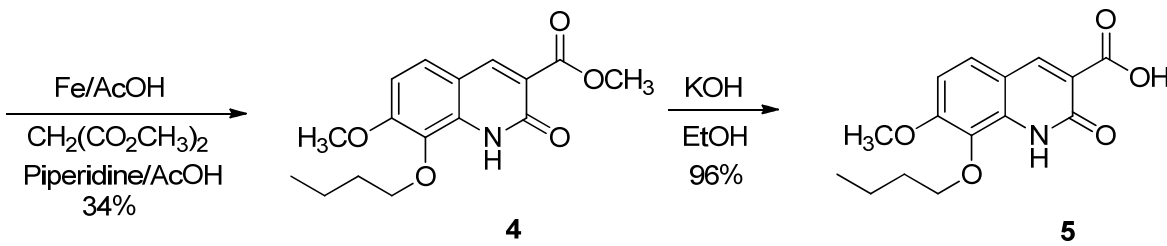

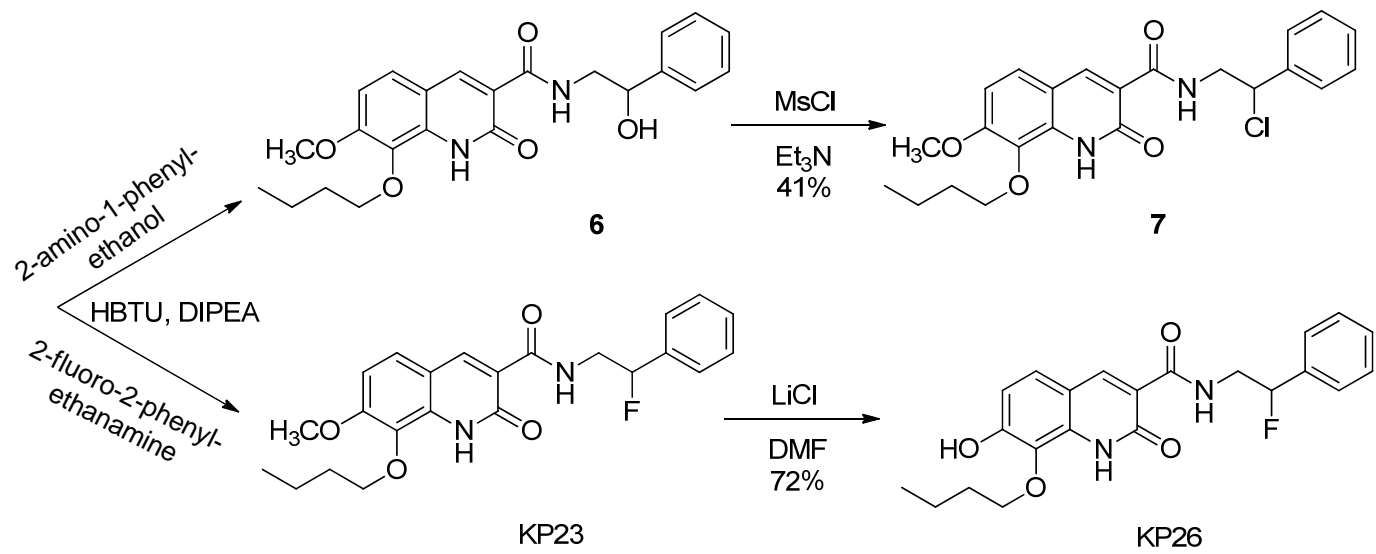

Scheme 2. Radiosyntheses of compounds $\left[{ }^{18} \mathrm{~F}\right] \mathrm{KP} 23$ and $\left[{ }^{11} \mathrm{C}\right] \mathrm{KP} 23$.<smiles>CCCCOc1c(OC)ccc2cc(C(=O)NCC(Cl)c3ccccc3)c(=O)[nH]c12</smiles>

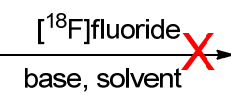<smiles>CCCCOc1c(OC)ccc2cc(C(=O)NCC(F)(F)c3ccccc3)c(=O)[nH]c12</smiles><smiles>CCCCOc1c(O)ccc2cc(C(=O)NCC(F)c3ccccc3)c(=O)[nH]c12</smiles>

KP26<smiles>CCCCOc1ccc2cc(C(=O)NCC(F)c3ccccc3)c(=O)[nH]c2c1OCCCCCCCCOC(C)(C)C</smiles>

\subsection{In Vitro Characterization}

In vitro competitive binding assays were performed with membranes obtained from CHO-K1 cells stably transfected with human CB1 and CB2, respectively, using $\left[{ }^{3} \mathrm{H}\right]-\mathrm{CP}-55940$. The binding affinity of the nonradioactive KP23 obtained from three independent experiments was $6.8 \pm 5.8 \mathrm{nM}$ towards human CB2 and $>10,000 \mathrm{nM}$ towards CB1, slightly lower affinity than the reported data of $0.8 \pm 0.3 \mathrm{nM}$ towards human CB2 and >10,000 nM towards CB1 [27]. The affinity and selectivity of KP23 towards 
CB2 are the highest among the known 2-oxoquinoline carboxylic acid derivatives including $\left[{ }^{11} \mathrm{C}\right] N E 40$, the first CB2 PET tracer evaluated in healthy human subjects which exhibits a $\mathrm{K}_{\mathrm{i}}$ value of $9.6 \mathrm{nM}$. Autoradiography with slices from rat and mouse spleen, an organ with high CB2 levels [31], demonstrated high binding which was blocked by excess GW4058233 (CB2 specific agonist), indicating specific binding of $\left[{ }^{11} \mathrm{C}\right] \mathrm{KP} 23$ to CB2 (Figure 1) in both cases. However, relatively high non-specific binding was observed in the spleen tissue (Figures 1 A2 and B2) which is not surprising considering the calculated $\log P$ value of 3.81 .

Figure 1. Autoradiography of rat (A) and mouse (B) spleen sections incubated with $0.6 \mathrm{nM}$ $\left[{ }^{11} \mathrm{C}\right] \mathrm{KP} 23$ in the absence of blocking agent (A1 and B1) or in the presence of excess blocking agent $1 \mu \mathrm{M}$ GW4058233 (A2 and B2).

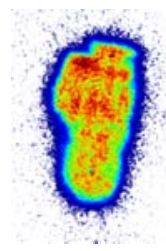

A1

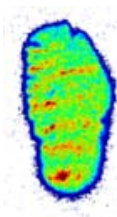

A2

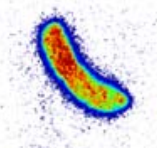

B1

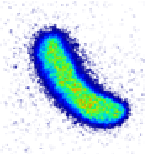

B2

In vitro plasma stability tests were carried out in PBS, mouse and rat plasma over a period of 40 min at $37^{\circ} \mathrm{C}$. No radioactive degradation products of $\left[{ }^{11} \mathrm{C}\right] \mathrm{KP} 23$ were detected (Figure 2).

Figure 2. Radio-UPLC profiles of $\left[{ }^{11} \mathrm{C}\right] \mathrm{KP} 23\left(\mathrm{t}_{\mathrm{R}}=2.1 \mathrm{~min}\right)$ after $2 \mathrm{~h}$ in PBS and after $40 \mathrm{~min}$ in mouse and rat plasma.
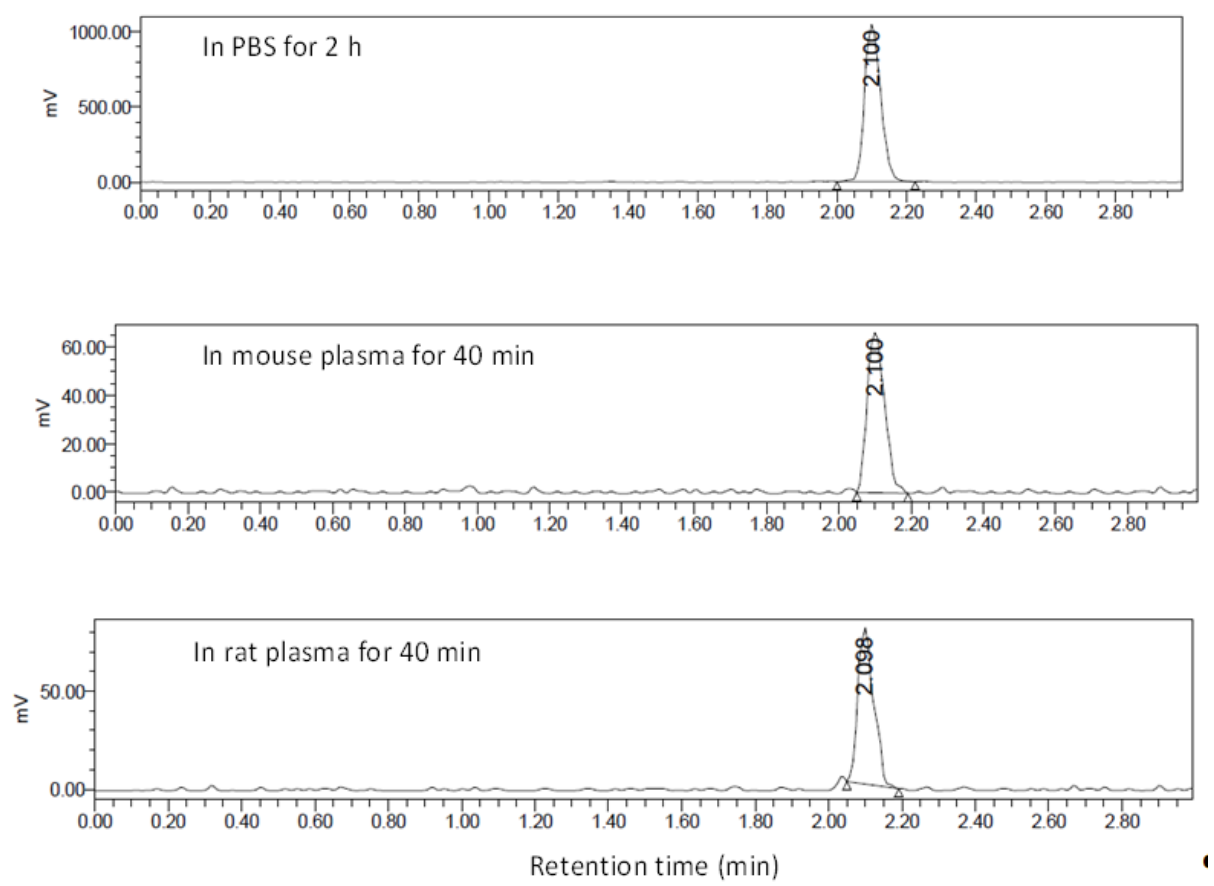

\subsection{In Vivo PET Imaging of $\left[{ }^{11} C\right] K P 23$}

Figure 3A shows PET images of a coronal section and maximal intensity projection (MIP) of the abdominal region of a rat fused to the respective $\mathrm{CT}$, and averaged from 6 to $15 \mathrm{~min}$ p.i. $\left[{ }^{11} \mathrm{C}\right] \mathrm{KP} 23$ 
accumulated in spleen, liver and intestines. The high spleen uptake is in accordance with the expression pattern of CB2 while the high accumulation in liver suggests a hepatobiliary elimination pathway. Background radioactivity in muscle tissue was relatively low. The TACs of liver, spleen and peripheral tissue outside the rips are shown in Figure 3B. Radioactivity peaked around 4 min p.i. for liver; the level of activity concentration steadily increased during the initial $8 \mathrm{~min}$ p.i. in spleen and then slowly washed out. During the whole data acquisition, the level of activity concentration was higher in the spleen region than in the background (flank).

Figure 3. PET/CT images of $\left[{ }^{11} \mathrm{C}\right] \mathrm{KP} 23$ in the spleen-liver region in rat. (A) Coronal section and maximal intensity projection (MIP) averaged from 6 to $15 \mathrm{~min}$ p.i. (B) TACs of $\left[{ }^{11} \mathrm{C}\right] \mathrm{KP} 23$ in spleen, liver and flank.
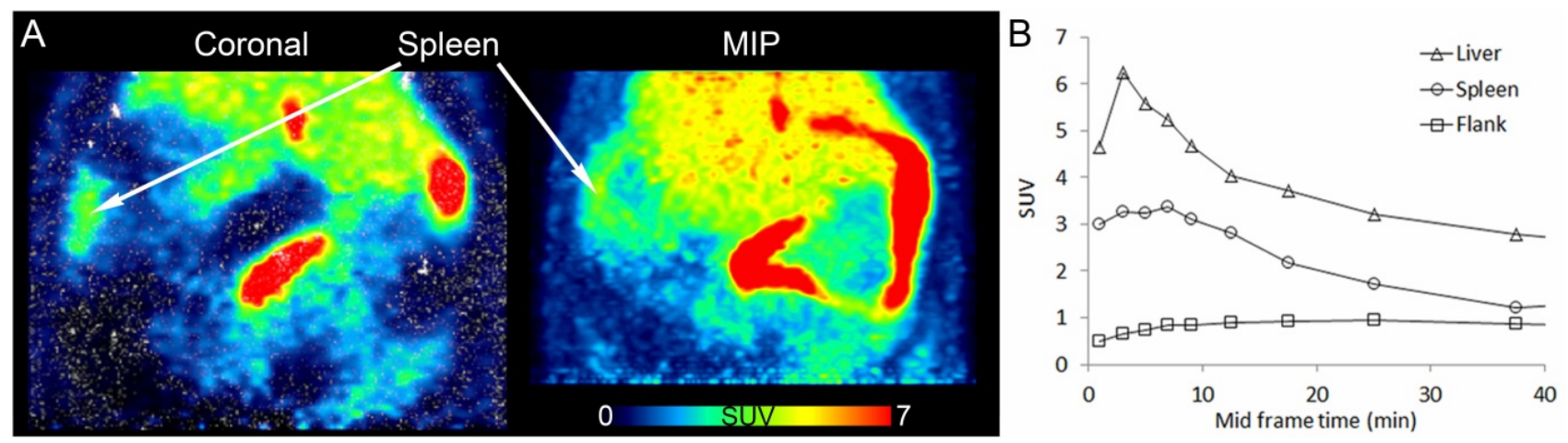

Distribution of the tracer in rat brain was evaluated by PET (Figure 4A). Region of interest TAC analysis showed low uptake in healthy rat brain which is in line with the low expression level of CB2 receptor (Figure 4B). Radioactivity levels in brain were lower than in peripheral tissues in general. The expression profile of CB2 provides great opportunities for PET imaging with low background in the brain region, whereas under inflammation conditions a 10-100-fold higher CB2 receptor density is expected in activated microglia [32].

Figure 4. $\left[{ }^{11} \mathrm{C}\right] \mathrm{KP} 23$ PET images of a rat brain superimposed on an MRI template . A: From left, axial, sagittal and coronal sections. In the last coronal image, regions of interest are encircled and used for TAC analysis shown in B. a, cortex; b, cerebellum; c, caudate putamen; d, hippocampus. Images are averaged from 2-60 min p.i. B TACs of rat brain regions of $\left[{ }^{11} \mathrm{C}\right] \mathrm{KP} 23$.
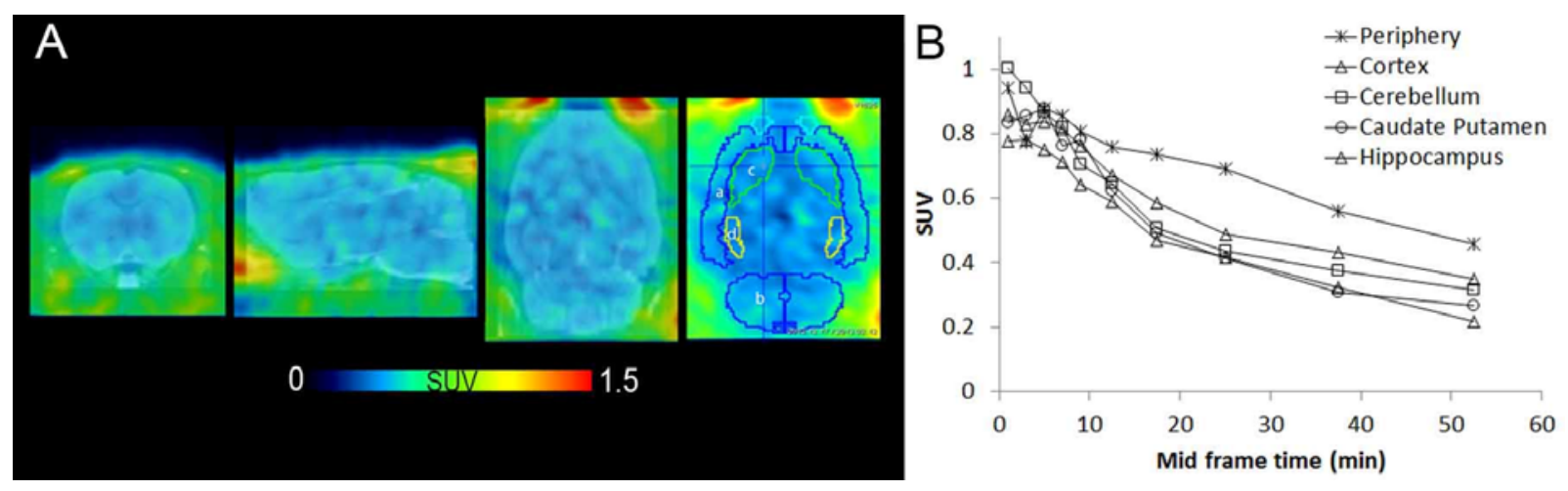


\subsection{In Vivo Metabolic Studies}

The metabolic fate of $\left[{ }^{11} \mathrm{C}\right] \mathrm{KP} 23$ was studied using blood and urine samples of a Wistar rat. In blood plasma samples, two to three radiometabolites which were more hydrophilic than the parent tracer, $\left[{ }^{11} \mathrm{C}\right] \mathrm{KP} 23$, were detected. As illustrated in Figure 5, one major radiometabolite slightly more polar than the parent compound was generated in blood plasma samples. The percentage of parent tracer radioactivity decreased to $40 \%$ at $15 \mathrm{~min}$ p.i., $25 \%$ at $30 \mathrm{~min}$ p.i. No intact compound could be found in the urine sample after $30 \mathrm{~min}$ p.i.

Figure 5. Radio-UPLC profiles of $\left[{ }^{11} \mathrm{C}\right] \mathrm{KP} 23$ metabolites in blood plasma samples obtained at $15 \mathrm{~min}$ and $30 \mathrm{~min}$ p.i. and in the urine sample obtained at $30 \mathrm{~min}$ p.i.
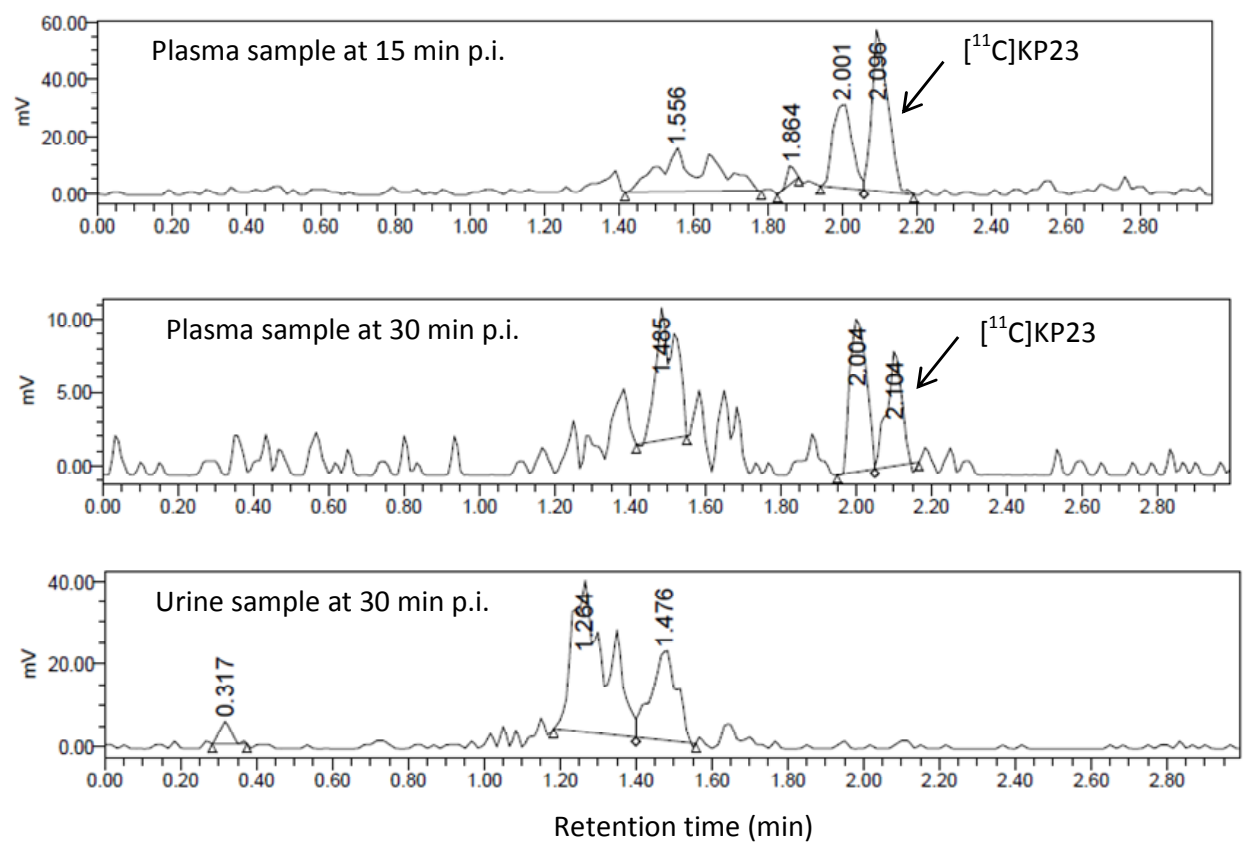

\section{Conclusions}

$\left[{ }^{11} \mathrm{C}\right] \mathrm{KP} 23$ showed promising in vitro characteristics. Its affinity and selectivity for $\mathrm{CB} 2$ is the highest among the known 2-oxoquinoline carboxylic acid derivatives. In vitro autoradiography with slices from rat and mouse spleen demonstrated specific binding. High spleen uptake of $\left[{ }^{11} \mathrm{C}\right] \mathrm{KP} 23$ was also observed in dynamic PET studies with Wistar rats. As expected, distribution to healthy rat brain was relatively low in the in vivo PET experiments. Further evaluation of $\left[{ }^{11} \mathrm{C}\right] \mathrm{KP} 23$ using neuroinflammation animal models which has higher CB2 expression levels in the brain is warranted.

\section{Acknowledgments}

This work was partially funded by the Swiss ALS Foundation. We thank Bruno Mancosu for his support with carbon-11 radiolabeling and Claudia Keller for performing the PET/CT scans. 


\section{Author Contributions}

L.M. planned and organized the whole study, responsible for radiolabeling, quality control, radiotracer stability studies both in vitro/in vivo and manuscript writing; R.S. Analyzed organic compounds ${ }^{1} \mathrm{H}-\mathrm{NMR},{ }^{13} \mathrm{C}-\mathrm{NMR}$, HRMS and performed the in vitro evaluation of $\mathrm{KP}-23$ and $\left[{ }^{11} \mathrm{C}\right] \mathrm{KP}-23$ including competitive binding assays and autoradiography; A.M. analyzed the PET data, helped writing the manuscript; K.P. Organic synthesis the precursor and reference compounds; S.Č. Involved in spleen tissue preparation and autoradiography experiments; M.W. Revision of the manuscript, final approval of the version to be published; R.S. Involved in the results discussion, final approval of the version to be published; S.D.K. supervision of and involved in the planning and interpretation of in vivo experiments; S.M.A. Involved in the experiments planning, revision of the manuscript.

\section{Conflicts of Interest}

The authors declare no conflict interest.

\section{References}

1. Vincent, B.J.; McQuiston, D.J.; Einhorn, L.H.; Nagy, C.M.; Brames, M.J. Review of cannabinoids and their antiemetic effectiveness. Drugs 1983, 25 (Suppl. 1), 52-62.

2. Console-Bram, L.; Marcu, J.; Abood, M.E. Cannabinoid receptors: Nomenclature and pharmacological principles. Prog. Neuropsychopharmacol. Biol. Psychiatry 2012, 38, 4-15.

3. Pertwee, R.G.; Howlett, A.C.; Abood, M.E.; Alexander, S.P.; di Marzo, V.; Elphick, M.R.; Greasley, P.J.; Hansen, H.S.; Kunos, G.; Mackie, K.; et al. International Union of Basic and Clinical Pharmacology. LXXIX. Cannabinoid receptors and their ligands: Beyond $\mathrm{CB}(1)$ and CB(2). Pharmacol. Rev. 2010, 62, 588-631.

4. Matsuda, L.A.; Lolait, S.J.; Brownstein, M.J.; Young, A.C.; Bonner, T.I. Structure of a cannabinoid receptor and functional expression of the cloned cDNA. Nature 1990, 346, 561-564.

5. Herkenham, M.; Lynn, A.B.; Johnson, M.R.; Melvin, L.S.; de Costa, B.R.; Rice, K.C. Characterization and localization of cannabinoid receptors in rat brain: A quantitative in vitro autoradiographic study. J. Neurosci. 1991, 11, 563-583.

6. Maresz, K.; Carrier, E.J.; Ponomarev, E.D.; Hillard, C.J.; Dittel, B.N. Modulation of the cannabinoid CB2 receptor in microglial cells in response to inflammatory stimuli. J. Neurochem. 2005, 95, 437-445.

7. Chin, C.L.; Tovcimak, A.E.; Hradil, V.P.; Seifert, T.R.; Hollingsworth, P.R.; Chandran, P.; Zhu, C.Z.; Gauvin, D.; Pai, M.; Wetter, J.; et al. Differential effects of cannabinoid receptor agonists on regional brain activity using pharmacological MRI. Br. J. Pharmacol. 2008, 153, 367-379.

8. Pertwee, R.G. Pharmacology of cannabinoid CB1 and CB2 receptors. Pharmacol. Ther. 1997, 74, 129-180.

9. Burns, H.D.; van Laere, K.; Sanabria-Bohorquez, S.; Hamill, T.G.; Bormans, G.; Eng, W.S.; Gibson, R.; Ryan, C.; Connolly, B.; Patel, S.; et al. [18F]MK-9470, a positron emission 
tomography (PET) tracer for in vivo human PET brain imaging of the cannabinoid-1 receptor. Proc. Natl. Acad. Sci. USA 2007, 104, 9800-9805.

10. Liu, P.; Lin, L.S.; Hamill, T.G.; Jewell, J.P.; Lanza, T.J., Jr.; Gibson, R.E.; Krause, S.M.; Ryan, C.; Eng, W.; Sanabria, S.; et al. Discovery of $N-\{(1 \mathrm{~S}, 2 \mathrm{~S})-2-(3-c y a n o p h e n y 1)-3-[4-(2-$ [18F]fluoroethoxy)phenyl]-1-methylpropyl -2-methyl-2-[(5-methylpyridin-2-yl)oxy]propanamide, a cannabinoid-1 receptor positron emission tomography tracer suitable for clinical use. J. Med. Chem. 2007, 50, 3427-3430.

11. Horti, A.G.; van Laere, K. Development of radioligands for in vivo imaging of type 1 cannabinoid receptors (CB1) in human brain. Curr. Pharm. Des. 2008, 14, 3363-3383.

12. Van Laere, K.; Casteels, C.; Lunskens, S.; Goffin, K.; Grachev, I.D.; Bormans, G.; Vandenberghe, W. Regional changes in type 1 cannabinoid receptor availability in Parkinson's disease in vivo. Neurobiol. Aging 2012, 33, 620.e1-8.

13. Van Laere, K.; Goffin, K.; Casteels, C.; Dupont, P.; Mortelmans, L.; de Hoon, J.; Bormans, G. Gender-dependent increases with healthy aging of the human cerebral cannabinoid-type 1 receptor binding using [(18)F]MK-9470 PET. Neuroimage 2008, 39, 1533-1541.

14. Van Laere, K.; Koole, M.; Sanabria Bohorquez, S.M.; Goffin, K.; Guenther, I.; Belanger, M.J.; Cote, J.; Rothenberg, P.; de Lepeleire, I.; Grachev, I.D.; et al. Whole-body biodistribution and radiation dosimetry of the human cannabinoid type-1 receptor ligand $18 \mathrm{~F}-\mathrm{MK}-9470$ in healthy subjects. J. Nucl. Med. 2008, 49, 439-445.

15. Muccioli, G.G.; Lambert, D.M. Current knowledge on the antagonists and inverse agonists of cannabinoid receptors. Curr. Med. Chem. 2005, 12, 1361-1394.

16. Raitio, K.H.; Salo, O.M.; Nevalainen, T.; Poso, A.; Jarvinen, T. Targeting the cannabinoid CB2 receptor: Mutations, modeling and development of CB2 selective ligands. Curr. Med. Chem. 2005, 12, 1217-1237.

17. Evens, N.; Muccioli, G.G.; Houbrechts, N.; Lambert, D.M.; Verbruggen, A.M.; Van Laere, K.; Bormans, G.M. Synthesis and biological evaluation of carbon-11- and fluorine-18-labeled 2-oxoquinoline derivatives for type 2 cannabinoid receptor positron emission tomography imaging. Nucl. Med. Biol. 2009, 36, 455-465.

18. Vandeputte, C.; Evens, N.; Toelen, J.; Deroose, C.M.; Bosier, B.; Ibrahimi, A.; van der Perren, A.; Gijsbers, R.; Janssen, P.; Lambert, D.M.; et al. A PET brain reporter gene system based on type 2 cannabinoid receptors. J. Nucl. Med. 2011, 52, 1102-1109.

19. Mu, L.; Bieri, D.; Slavik, R.; Drandarov, K.; Muller, A.; Cermak, S.; Weber, M.; Schibli, R.; Kramer, S.D.; Ametamey, S.M. Radiolabeling and in vitro/in vivo evaluation of $N$-(1-adamantyl)8-methoxy-4-oxo-1-phenyl-1,4-dihydroquinoline-3-carboxamide as a PET probe for imaging cannabinoid type 2 receptor. J. Neurochem. 2013, 126, 616-624.

20. Evens, N.; Vandeputte, C.; Coolen, C.; Janssen, P.; Sciot, R.; Baekelandt, V.; Verbruggen, A.M.; Debyser, Z.; van Laere, K.; Bormans, G.M. Preclinical evaluation of [11C]NE40, a type 2 cannabinoid receptor PET tracer. Nucl. Med. Biol. 2012, 39, 389-399.

21. Turkman, N.; Shavrin, A.; Paolillo, V.; Yeh, H.H.; Flores, L.; Soghomonian, S.; Rabinovich, B.; Volgin, A.; Gelovani, J.; Alauddin, M. Synthesis and preliminary evaluation of [18F]-labeled 2-oxoquinoline derivatives for PET imaging of cannabinoid CB2 receptor. Nucl. Med. Biol. 2012, $39,593-600$. 
22. Ahmad, R.; Koole, M.; Evens, N.; Serdons, K.; Verbruggen, A.; Bormans, G.; van Laere, K. Whole-body biodistribution and radiation dosimetry of the cannabinoid type 2 receptor ligand [11C]-NE40 in healthy subjects. Mol. Imaging Biol. 2013, 15, 384-390.

23. Showalter, V.M.; Compton, D.R.; Martin, B.R.; Abood, M.E. Evaluation of binding in a transfected cell line expressing a peripheral cannabinoid receptor (CB2): Identification of cannabinoid receptor subtype selective ligands. J. Pharmacol. Exp. Ther. 1996, 278, 989-999.

24. Ruhl, T.; Deuther-Conrad, W.; Fischer, S.; Gunther, R.; Hennig, L.; Krautscheid, H.; Brust, P. Cannabinoid receptor type 2 (CB2)-selective N-aryl-oxadiazolyl-propionamides: Synthesis, radiolabelling, molecular modelling and biological evaluation. Org. Med. Chem. Lett. 2012, 2, 32.

25. Wang, Y.; Seidel, J.; Tsui, B.M.; Vaquero, J.J.; Pomper, M.G. Performance evaluation of the GE healthcare eXplore VISTA dual-ring small-animal PET scanner. J. Nucl. Med. 2006, 47, 1891-900.

26. Honer, M.; Bruhlmeier, M.; Missimer, J.; Schubiger, A.P.; Ametamey, S.M. Dynamic imaging of striatal D2 receptors in mice using quad-HIDAC PET. J. Nucl. Med. 2004, 45, 464-470.

27. Turkman, N.; Shavrin, A.; Ivanov, R.A.; Rabinovich, B.; Volgin, A.; Gelovani, J.G.; Alauddin, M.M. Fluorinated cannabinoid CB2 receptor ligands: Synthesis and in vitro binding characteristics of 2-oxoquinoline derivatives. Bioorg. Med. Chem. 2011, 19, 5698-5707.

28. Bacherikov, V.A.; Chou, T.C.; Dong, H.J.; Zhang, X.G.; Chen, C.H.; Lin, Y.W.; Tsai, T.J.; Lee, R.Z.; Liu, L.F.; Su, T.L. Potent antitumor 9-anilinoacridines bearing an alkylating N-mustard residue on the anilino ring: Synthesis and biological activity. Bioorg. Med. Chem. 2005, 13, 3993-4006.

29. Savle, P.S.; Medhekar, R.A.; Kelley, E.L.; May, J.G.; Watkins, S.F.; Fronczek, F.R.; Quinn, D.M.; Gandour, R.D. Change in the mode of inhibition of acetylcholinesterase by (4-nitrophenyl)sulfonoxyl derivatives of conformationally constrained choline analogues. Chem. Res. Toxicol. 1998, 11, 19-25.

30. Boeckman, R.K.; Miller, Y.; Savage, D.; Summerton, J.E. Total synthesis of a possible specific and effective acid-targeted cancer diagnostic, a camphor derived bis- $N$-oxide dimer. Tetrahedron Lett. 2011, 52, 2243-2245.

31. Gong, J.P.; Onaivi, E.S.; Ishiguro, H.; Liu, Q.R.; Tagliaferro, P.A.; Brusco, A.; Uhl, G.R. Cannabinoid CB2 receptors: Immunohistochemical localization in rat brain. Brain Res. 2006, 1071, 10-23.

32. Evens, N.; Bormans, G.M. Non-invasive imaging of the type 2 cannabinoid receptor, focus on positron emission tomography. Curr. Top. Med. Chem. 2010, 10, 1527-1543.

(C) 2014 by the authors; licensee MDPI, Basel, Switzerland. This article is an open access article distributed under the terms and conditions of the Creative Commons Attribution license (http://creativecommons.org/licenses/by/3.0/). 